\title{
Understanding of Science Literacy for Prospective Physics Teachers of the Physics Education Program
}

\author{
$1^{\text {st }}$ Widodo Budhi ${ }^{1}, 2^{\text {nd }}$ Ayu Fitri Amalia ${ }^{2}$ \\ \{budhiust@yahoo.comªyufitriamalia@ustjogja.ac.id $\left.{ }^{2}\right\}$ \\ Departement of Physics Education Universitas Sarjanawiyata Tamansiswa, Indonesia ${ }^{12}$
}

\begin{abstract}
The research aimed to know the tendency of understanding the science literacy in the 2nd Fundamental Physics lesson for students of physics teacher prospective in the Physics Education program of FKIP UST of academic year 2016/2017. The research implemented in the Physics Education program of FKIP UST Yogyakarta in the even semester of the 2016/2017 academic year. The populations of this research were 48 students of Physics Education program of FKIP UST that studied about 2nd Fundamental Physics lesson in the even semester of the 2016/2017 academic year, all members of the population became the sample of the research, thus this research was a case study. The instruments used in this research were the test of understanding the science literacy in the 2nd Fundamental Physics lesson (static electricity, dynamic electricity, magnetic field). In the data collecting, the researcher used a test technique. In the analyzing the data, the researcher used descriptively by comparing the average score obtained by the student with criteria of normal idea curve. Based on the result of the research, it showed that the tendency of understanding science literacy in the 2nd Fundamental Physics lesson for students of physics teacher candidate in the Physics education program study of FKIP UST of the 2016/2017 academic year are in the medium category. Each subject of static electricity is the medium category and dynamic electricity and magnetic field are the lowest categories.
\end{abstract}

Keywords. Literacy, Science, Physics

\section{Introduction}

Current scientific literacy has become a widespread concern for scientists, lecturers, and policymakers because it is necessary for modern society to deal with various problems of science and technology, and to support sustainable development. Science Literacy according to the National Science Education Standards is knowledge and understanding of the concepts and processes needed to produce personal decisions, in civil cultural issues, and in productive economics[1]. 
Knowledge standards for mathematics teacher education include knowledge, knowledge, and pedagogics. Indicators of candidates for physics teachers who understand science literacy are realizing and understanding science and technology in daily life, making personal decisions about things including science, health, the use of energy sources, reading and understanding important things from media reports about science material, criticizing automatically, participate in discussions with full confidence about science issues.

Development of scientific literacy is recognized as the main goal of physics education in the world. Therefore, the qualification standard for the undergraduate level is a student of physics teacher candidates who must be able to apply their expertise and utilize science and technology in their fields in solving problems and be able to adapt to the situation at hand.

The Physics Education Program of FKIP UST Yogyakarta stipulates that the Physics Education Program Graduation Standards include: (1) mastery of material, structure, competence, concepts of physics and its application in technology, (2) application of principles, concepts and laws of physics in the form of prototypes of science and technology that are relevant to the needs of the community, (3) able to utilize information and communication technology for the benefit of strengthening and disseminating scientific products.

The development of scientific literacy for physics teacher prospectives is a challenge for learning in universities today. The survey results in 1988-2008 showed that the increase in scientific literacy of university students in America was not significant, and scientific literacy in Turkey was also low[2]. The main problems in Physics lectures in Indonesia are generally due to the presence of several lecturers who do not understand or care less about learning outcomes, learning strategies and methods, and inappropriate evaluation methods. The development of scientific literacy is urgently needed to help physics teacher prospectives understand scientific literacy content and elements of scientific literacy, and be able to use appropriate learning methods as key mechanisms that will guide students to develop scientific literacy in the classroom[1]. Literacy is one of the abilities to use knowledge, identify, draw with evidence in order to make the right decisions.

This condition encourages researchers to conduct preliminary research in order to provide information about understanding scientific literacy of prospective students of the Physics Education Program of FKIP UST Yogyakarta in the 2016/2017 academic year. The formulation of the problem in this study is the extent to which the tendency of scientific literacy understanding of prospective students of the Physics Education Program of FKIP UST Yogyakarta in the 2016/2017 academic year. While the purpose of the study was to find out the scientific literacy trends of prospective physics teacher students.

The term scientific literacy began to emerge in the late 1950s, but the notions put forward about the term were not always the same. Literally means be educated, while science means natural knowledge. Science literacy can be interpreted as an understanding of science and its application to the needs of society[3]. While Holbrook states that literacy is a useful method in science by encouraging learning components in a social environment[4]. In the PISA context, scientific literacy is defined as the ability to use scientific knowledge, identify questions and draw conclusions based on evidence in order to understand and make decisions regarding nature and the changes made to nature through human activities[5].

The Organization for Economic Cooperation and Development, explains that understanding literacy in this language is to explain, and translate data, and interpret data and provide scientific evidence[6]. While the three major dimensions of literacy are included in the measurement, content process, and application applications. In PISA 2006 the literacy dimension was accepted into four dimensions, in addition to aspects of student attitudes 
toward science[7]. Thus, it can be concluded that literacy can be used as a form of ability to implement, make decisions, and analyze relationships with the environment, technology, and society. The form of interaction can be through communication using scientific knowledge obtained.

PISA sets three aspects of the components/processes of science in scientific literacy assessment, namely identifying scientific questions, explaining phenomena scientifically, and using scientific evidence. One conclusion of research conducted by Millers in Hobson relating to scientific literacy states that global scientific literacy is very low. The low level of scientific literacy skills of students is a reason that underlies the goverment to revise the 2006 to 2013 curriculum. To categorize students' abilities in scientific literacy Bybvee in Soobard and Rannikmae propose a framework consisting of four levels, namely nominal, functional, procedural, and multidimensional[8].

Fives, et.al. summarizes the aspects of scientific literacy, namely the role of science, including identifying questions that can be answered through scientific investigation, understanding the nature of business / scientific activities, and understanding the concepts of generic science[9]. Thinking and working aspects scientifically include explaining natural phenomena, recognizing patterns, identifying research variables, asking critical questions about research design, and obtaining / evaluating conclusions based on evidence, aspects of science and society including: applying scientific conclusions in daily life, identifying scientific issues that underlie policy decisions, understand the role of science in making decisions, develop questions to assess the validity of scientific reports, and ask for sources of scientific reports, mathematical aspects.

\section{Method}

This research is a type of descriptive research. The study population was 48 students who took 2nd Fundamental of Physics courses, all members of the population became the research sample. Research variables include: understanding scientific literacy. Research data was collected by test techniques. Research instruments in the form of scientific literacy tests. Scientific literacy tests include material in 2nd Fundamental of Physics with substances of Electrostatics, Electrodynamics, and Magnetic Fields. The scientific literacy test grid is presented in the Table I.

Tabel 1. The grid of Science Literacy Tests

\begin{tabular}{|c|c|c|c|c|c|c|c|c|}
\hline \multirow{2}{*}{ No. } & \multirow{2}{*}{ Subtances } & \multicolumn{6}{|c|}{ Item Number } & \multirow{2}{*}{ Total } \\
\hline & & $\mathrm{C} 1$ & $\mathrm{C} 2$ & C3 & $\mathrm{C} 4$ & C5 & C6 & \\
\hline 1. & Electrostatics & - & 1,9 & 3 & $\begin{array}{l}2,4, \\
5,6 \\
8,10\end{array}$ & - & 7 & 10 \\
\hline 2. & Electrodynamics & - & $\begin{array}{l}16 \\
17\end{array}$ & - & $\begin{array}{c}12 \\
13 \\
15 \\
19\end{array}$ & - & $\begin{array}{l}11, \\
14, \\
18, \\
20\end{array}$ & 10 \\
\hline 3. & Magnetic Fields & - & $\begin{array}{l}22, \\
25,\end{array}$ & - & $\begin{array}{l}23, \\
24,\end{array}$ & - & $\begin{array}{l}21, \\
26\end{array}$ & 10 \\
\hline
\end{tabular}




\begin{tabular}{|l|c|c|c|c|c|c|c|c|}
\hline & & 28 & & 27, & & & \\
& & & & & 29, & & & \\
& & & & & & \\
\hline Total & - & 7 & 1 & 15 & - & 7 & 30 \\
\hline
\end{tabular}

with:
$\mathrm{C} 1=$ Knowladge
$\mathrm{C} 4=$ Analysis
$\mathrm{C} 2$ = Understanding
C5 $=$ Syntesis
C3 = Application
C6 = Evaluation

Descriptive data analysis techniques by comparing the average score against the ideal normal curve criteria as follows.

$(M+1,5 S D) \leq \bar{X} \leq$ Ideal maximum score

$(M+0,5 S \mathrm{D}) \leq \bar{X}<(M+1,5 S D)$

$$
\begin{aligned}
& =\text { very high } \\
& =\text { high } \\
& =\text { medium } \\
& =\text { low } \\
& =\text { very low }
\end{aligned}
$$

$(M-1,5 S D) \leq \bar{X}<(M-0,5 S D)$

Ideal minimum score $\leq \bar{X}<(M-1,5 S D)$

with:

$\mathrm{M}=0,5 \times$ (Ideal maximum score + Ideal minimum score $)$

$\mathrm{SD}=0,167 \mathrm{x}$ (Ideal maximum score + Ideal minimum score $)$

\section{Results and Discussion}

This initial research was expected to get information about scientific literacy understanding of prospective physics teacher students of Physics Education Program of FKIP UST based on scientific literacy test results. The results showed that the understanding of scientific literacy of prospective Physics Education Program of FKIP UST was in the medium category with an average score of 13.08. This is because most students do not master the concept of physics correctly. Most students only answer questions but cannot give reasons why they chose the option.

In the sub-material, Electrostatic in understanding scientific literacy in prospective physics teacher students was also in the medium category with an average score of 5.60. It was also caused by the students that were not mastering the concept of physics correctly and how to apply the concept of physics in solving problems.

In the sub-material of Electrodynamic and Magnetic Field, students' understanding of scientific literacy was very low with an average score of 2.58 and 2.60 , respectively. It was because they also did not master the concept of physics properly and correctly.

Students generally mastered the theory of electrostatic, electrodynamic, and magnetic fields but have difficulty using various scientific process skills needed in scientific inquiry to find the expected information. In general, students could not analyze and interpret data and describe conclusions that were appropriate. 


\section{Conclusions}

The outcomes of this study are the tendency of understanding scientific literacy for prospective physics teacher students of the Physics Education Program of FKIP UST $2016 / 2017$ academic year is in the medium category. The tendency of scientific literacy in the electrostatic materials are in the medium category, in the electrodynamic materials are in the very low category, and in the Magnetic Field materials are in the very low category.

\section{Acknowledgment}

We are grateful to teamwork in Physics Education Program of FKIP UST for numerous discussions on the subject of this work. This research is based upon work supported by LP3M UST.

\section{References}

[1] T. Sunarti, "Pemahaman Literasi Sains Mahasiswa Calon Guru Fisika Universitas Negeri Surabaya," in Seminar Nasional Fisika dan Pembelajarannya 2015, 2015, pp. 34-39.

[2] C. Impey, "Science literacy of undergraduates in the united states," Organ. People Strateg. Astonomy 2 (OPSA 2), vol. 2, no. Opsa 2, pp. 353-364, 2013.

[3] Usmeldi, "Pengembangan Modul Pembelajaran Fisika Berbasis Riset dengan Pendekatan Scientific untuk Meningkatkan Literasi Sains Peserta Didik," J. Penelit. dan Pengemb. Pendidik. Fis., vol. 2, no. 1, pp. 1-8, 2016. 
[4] K. Bashooir and Supahar, "Analisis Aspek Kinerja Liiterasi Sains Pada Materi Kalor Fisika," Unnes Phys. Educ. J., vol. 5, no. 1, pp. 89-95, 2016.

[5] J. P. Biologi, F. Universitas, and P. Indonesia, “Analisis Buku Ajar Biologi Sma Kelas X Di Kota Bandung," pp. 1-13, 2008.

[6] A. Ariningtyas, S. Wardani, and Widhi Mahatmanti, "Efektivitas Lembar Kerja Siswa Bermuatan Etnosains Materi Hidrolisis Garam untuk Meningkatkan Literasi Sains Siswa SMA," J. Innov. Sci. Educ., vol. 6, no. 2, pp. 186-196, 2017.

[7] D. J. Delin, D. Djamas, and Yohandri, "Analisis Karakteristik Peserta Didik Berdasarkan Dimensi Literasi Sains Pada Pengembangan Performance Assessment Berbasis Discovery Learning," in PROSIDING SEMINAR NASIONAL PEMBELAJARAN FISIKA, 2015, pp. 310-314.

[8] R. Soobard and M. Rannikmäe, "Assessing Student's Level of Scientific Literacy Using Interdisciplinary Scenarios," Sci. Educ. Int., vol. 22, no. 2, pp. 133-144, 2011.

[9] S. Diana, A. Rachmatullah, and E. S. Rahmawati, "Profil Kemampuan Literasi Sains Siswa SMA Berdasarkan Instrumen Scientific Literacy Assesments (SLA)," Pros. Semin. Nas. XII Pendidik. Biol. FKIP UNS 2015, pp. 285-291, 2015. 